Global Conferences Series:

Social Sciences, Education and Humanities (GCSSSEH), Volume 3, 2019

The $1^{\text {st }}$ International Conference on Education, Social Sciences and Humanities

DOI: https://doi.org/10.326/hum0215

\title{
The view of "Ngeli Nanging Ora Keli" in facing era of 4.0 Industrial Revolution (The approach of Indigenous Psychology at Java ethnic)
}

\author{
Asih Menanti ${ }^{1 *}$, Abdul Munir ${ }^{2}$, Abdul Murad ${ }^{3}$, Asiah $^{4}$ \\ 1,2,3,4 Universitas Negeri Medan, Medan, Indonesia, \\ asihmenanti9@gmail.com
}

\begin{abstract}
This study was formed the background of experts response on the psychology approach built from western culture, that its application did not definitely conform to the eastern culture in Indonesia yet. The response produced psychology indigenous approach. This approach analyzes problem departing from individual's indigenous culture or local society. Focusing on the life view of Java ethnic "ngeli nanging ora keli" (means following flows but not washed away), be analyzed employing psychology indigenous approach in morality. This study aimed at analyzing the view function ngeli nanging ora keli at Java ethnic morality by employing literature study method that next to interpreting the empirical finding of moral reasoning in Indonesia. The finding founded in this study is that view of ngeli nanging ora keli functions as moral control in facing life on the fourth industrial revolution era. It was concluded that Java ethnic has to place their life view on the highly moral reasoning orientation.
\end{abstract}

Keywords: Indigenous psychology, Java, 4.0 industrial revolution

\section{Introduction}

Morality is the heart of human life and more classic. If body is physically sick, deformity, low economy, then it can be searched for solution. On the contrary, if moral has lost, then there will be happened a crime in a number of places, life can be chaotic, it can be moreover extinct earlier. Moral problem gets more attention in Indonesia, that is why, in the recent development it is often happened crime and delinquency cases that is mostly worried about them such as looting, robbery, act of despising, violence, drugs abuse, corruption, lack of school discipline. The moral weakening comes into education world and penetrates into nuclear family. The government attention on morality was realized in varieties of laws and rules. Among them, Law of Republic of Indonesia Number 20 Year 2003 stated national education objective to shape Indonesian peoples that had moral besides smart and creative. The government rule of Republic of Indonesia Number 87 Year 2017 decided on reinforcement of education character.

Copyright (C) 2019, the Authors. Published by Redwhite Press.

Page | 181

This is an open access article under the CC BY-NC license

(http://creativecommons.org/licenses/by-nc/4.0). 
Global Conferences Series: Social Sciences, Education and Humanities (GCSSSEH), Volume 3, 2019

This paper aimed at analyzing a life view of Java ethnic that functions as moral control, that sounds ngeli nanging ora keli. Ngeli nanging ora keli. It meant that a Javanese follows period flows, but not washed away by bad flows. This analysis was done to answer three questions as follows: 1 . Can the life view of ngeli nanging ora keli function as Javanese ethnic's moral control at the era of 4.0 industrial revolution? 2. Can the life view of ngeli nanging ora keli be reinforced by moral reasoning in effort of increasing Javanese ethnic's moral control in facing 4.0 industrial revolution? 3. Can the moral reasoning create to moral behavior?

Javanese is one of nation ethnic available in Indonesia, recognized as nation ethnic that has high tolerance, highly polite, and unique in case of that they work starting from lower class such as house keeper to highest class job, as president. According to Geertz (1982), Setiono (1984), Javanese ethnic emphasizes the values of respect and harmonious. Respect contains the feeling of wedi (fear), isin (ashamed), and shy (keep in one's place). Respect referees to the social relation that places on the older man/woman, employer, boss, positioned more respected by the younger, employee, staff. Harmonious referees to social relation that avoids dispute, conflict, principle difference. For harmonious Javanese did self-adaptation, tolerance. This tolerance was disclosed in view of sounding, "ngeli nanging ora keli" (Setiono, 1994). On the era of 4.0 industrial revolution nowadays, life view ngeli nanging ora keli is critical to find reinforcement to strengthen its function as moral control, namely through mature reasoning moral. The moral reasoning is reasoning or reason employed in taking decision or action from moral perspective (right-false, good-bad, reasonable-unreasonable, proper-improper).

The reasoning moral theory was proposed by Kohlberg, including in the group of cognitive theory from three famous theories in psychology, namely theories of psychoanalytic, behaviorism, and cognitive (Aronfreed in Lickona, 1976). This reasoning moral theory limited study in the cognitive moral domain. Kohlberg proposed three moral reasoning levels, each levels consist of two stages (Arbuthnot and Faust, 1981, Smetana and Turiel in Adams and Berzonsky, 2003, Steinberg, 2002, Reimer, Paolitto, and Hers, 1983, Kohlber in Lickona, 1976, Velasque, 2002, Menanti, 2008). Level I (pre-conventional moral), at stage 1 , individual orients to authority owner moral like parent. The referred moral is moral performed by authority owner. At stage 2, moral orientation is on the mutual relationship each other. Level II (conventional moral), at stage 3 , it orients to morality in order to be called a good person. At stage 4, moral orientation is on the effort of maintaining the prevailing rule. Level III (post-conventional moral), at stage 5, moral orientation is to watch on the public interest, and at stage 6 , oriented to the universal values like human right, right for alive.

According to moral reasoning theory, moral optimal is to reach mature moral reasoning, namely postconventional level. The level of moral reasoning achievement was based by intelligence (Monks, et al., 2002) and intelligence described the thinking level. In accordance with the thinking levels proposed by Piaget (Ginsburg and Opper, 1979), so post-conventional level of moral reasoning could only be achieved by individual who owned the formal operation thinking level.

The moral reasoning achievement on the post-conventional level for the western society/adolescent. Although from research findings conducted in Indonesia since 1982 by Setiono, then done by Menanti (1990), Supartini (1999), Maryani (2005), Rosito (2006), Oki P. S. (2007), (Menanti (2008, 2003), up to 2018 by Amanda, Sinaga (2018), Sigiro (2018), Damanik (2018), generally adolescent achieved conventional level of moral reasoning. Menanti (2018) in her research concluded that adolescent's moral reasoning optimal to conventional moral level was influenced by the interdependent cultural orientation factor. The interdependent values orientation was in conformity with moral reasoning characteristics of conventional 
level. Javanese ethnic directs the interdependent values they considered noble such as conforming, selfadjusting, nobble person in accordance with norm.

The life view of ngeli nanging ora keli is strengthened by moral reasoning of post-conventional level through dominantly ratio (moral reasoning) before deciding or acting from moral perspective and controlling on feeling encouragements, emotion, that caused to be taking wrong decision and action. Higher moral reasoning level in taking decision or acting, more involving so many related parties, more comprehensive, and applying righteous values prevailing universally. The life view ngeli nanging ora keli was strengthened by moral reasoning to function as a Javanese's moral control in facing 4.0 industrial revolution era fluctuation.

\section{Method}

The study employed literature study next to be used to interpret the empirical findings about the moral reasoning in Indonesia. The subject of this study was nation ethnic of largest population in Indonesia, namely 95,2\% (National Statistic Corporation, 2010), meanwhile, Indonesian populations in 2017 amount to 261.890 .900 persons (Statistic Center Corporation, 2018). The life view in the moral theme was selected, namely sounding, "ngeli nanging ora keli. The empirical data on the interpreted moral reasoning were data of twelve research findings on subjects orienting to the interdependent culture, researched from 1982 to 2018. The data collection of moral reasoning used Defining Issues Test (DIT), organized by Rest (1979). DIT had been validated in variety of different culture, including it had been tried out by Menanti (2008) to Malay ethnic adolescent in Langkat district, North Sumatra Province, Indonesia. The data analysis was conducted qualitatively. The reinforcement findings by moral reasoning of post-conventional level on view of ngeli nanging ora keli, namely becoming Javanese ethnic's moral control, becoming findings.

\section{Results and Discussion}

\section{Life view of ngeli nanging ora keli functions as moral control}

The life view of ngeli nanging ora keli can functions as moral control at Javanese ethnic in facing 4.0 industrial revolution era caused the following things :

First, individual is strengthened by the existing of the mature moral reasoning (post-conventional level), so that they decide something by employing ratio (moral reasoning) with a wide perspective and value principle righteous which is prevailing and admitted universally. This such decision is more accepted by environment and avoids the decision that is able to harm either him/herself or others. Secondly, the mature moral reasoning plays role to control bad feeling drive/ bad impulsive emotion. Third, the mature moral reasoning appears highly commitment between life view and behavior ngeli nanging ora keli. This means more consistently performing life view of ngeli nanging ora keli obviously in alive. Fourth, the life in the era of 4.0 industrial revolution needed persons who owned high moral reasoning and moral behavior. With mature moral reasoning and moral behavior, either life in the era of 4.0 industrial revolution or after this era can more comfortably be undergone by Javanese ethnic. The 4.0 industrial revolution era purposed can be undergone more comfortably. It is from negative impact that is emerged, such as life style with so very busy for working business, lack of having social interaction, lack of social care, Society control function and religion becoming weak, low idealism, child's behavior less of respecting his parent, more higher opportunity to divorce, the existing of unhealthy life styles like an offer of served ready foods, drugs abuse, LGBT, bad political life.

Life view of ngeli nanging ora keli is reinforced by moral reasoning in effort of increasing moral control 
Global Conferences Series: Social Sciences, Education and Humanities (GCSSSEH), Volume 3, 2019

Life view of ngeli nanging ora keli is reinforced through owning the mature moral reasoning level employed at the time of individual is facing social moral problems in life situation of 4.0 industrial revolution era. The moral reasoning potential appeared in form of reasons/thinking/judgment deciding good-bad, right-false, reasonable-unreasonable, proper-improper, from the life view application problems or cases, ngeli nanging ora keli. For example, the life view of ngeli nanging ora keli owned by Javanese people, does not make them rejecting to associate with persons who are in contradictory to his/her opinion or his/her reference group, moreover differing principally, but he remained holding on to his own principle and opinion or his reference group. Here, a Javanese does not reject the general habit flows to associate with particular persons with only one principle or the general habit to reject, compete against persons in contradicting to his opinion, but a Javanese efforts associating with everyone wisely, although he did not follow things not in accordance with his life view. He avoided conflict. The life view of ngeli nanging ora keli is strengthened by moral reasoning that thought that everyone have right to determine his attitude choice such as in associating and have right to hold on to his convinced principle. Here, individual employs moral reasoning of post-conventional level.

Moral reasoning is predicted realizing into moral behavior.

Moral reasoning did not guarantees continuing to moral behavior, but becoming predictor on positive correlation and impact that can be categorized strong enough. Higher moral reasoning, more consistently between thought and action, this was tested from some experimental studies proposed by McNamee, studi Haan, Smith, and Block (Kohlberg and Candee in Kurtines and Gerwitz, 1984). According to Rest (1983) (in Steinberg, 2002), Menanti (2008) generally individual thinking at the higher moral reasoning level, behaving in more honorable ways.

Factors influencing so moral reasoning cannot fully guarantee to be going to be realized to moral behavior. They are internal factors such as individual's need that will be fulfilled by him, individual moral motivation, and external factors such as environmental tension that force individual employing the low moral behavior, although he owned high moral reasoning (Post-conventional level). If departing from Maslow's theory on basic needs, it could be explained that there were individuals whose basic need dominance on the low level (physiologic) and there were on the higher level, such as need of self-esteem, need of self-actualization. The persons who has dominant basic needs to the higher self-esteem and those self-esteems is placed on economy, it can be happened when he experiences social moral problems, he employed choice that fulfills his economic need, although he owned moral reasoning of postconventional level. He ignores it. The impact of this need factor on the moral behavior can be become example to motivation factor. This means economic motivation makes someone employing the lower moral reasoning, although he already owns high moral reasoning.

\section{Discussion}

Life view of ngeli nanging ora keli functions as Javanese ethnic's moral control, and this moral control can be reinforced by mature moral reasoning ownership support, namely post-conventional level. The problem emerges on the Javanese ethnic's moral reasoning achievement, focusing on the conventional level of moral reasoning. This is refraction of the interdependent culture, not because they are unable to achieve moral reasoning of post-conventional level. Suseno (1988) told the prominent characteristics of Javanese's ethics were holistically in conformity with level III (conventional level). The moral reasoning achievement at this conventional level centered on the judgment that a honorable person is someone fulfilling requirements called as good person, or if he conforms with the existed norms/rules. When the interdependent cultural orientation proposed by Markus and Kitayama (In Matsumoto, 2004, 2000) was applied to Javanese ethnic, then they maintained interdependence, kept norm system that has existed, 
Global Conferences Series: Social Sciences, Education and Humanities (GCSSSEH), Volume 3, 2019

adjusted self to be fit, to be good person and conform. The interdependent cultural orientation and/or moral reasoning of conventional level like conform, contains possibly washed away by bad flows, because his moral reasoning still depends upon environment, not owning moral values that comes from inner self yet.

Solution for the interdependent cultural orientation bias on Javanese ethnic mentioned above was done by stimulating moral reasoning in order to achieve moral reasoning of post-conventional level. This stimulation program is done by providing opportunity to individual to interact with others owning postconventional moral reasoning, the interdependent and independent oriented person, person with different character, different age, job variation, education level difference. The interaction can be done either face to face directly or through online media. Besides that, individual can be stimulated with discussion ways discussing social moral events happened from information sources such as newspaper, television, and events happened in the around environment. With this rich social interaction, individual is expected experiencing the moral reasoning promotion.

The moral reasoning promotion follows mechanism as follows: the social interaction can appear, in turn it cannot appear role taking. The rich role taking can appear socio-cognitive conflict, on the contrary, it can be happened. The less strong role taking does not appear socio-cognitive conflict. If socio-cognitive conflict can be accomplished by individual by employing moral reasoning of post-conventional level, then moral reasoning increases. Meanwhile, if socio-cognitive conflict cannot be accomplished or accomplished by employing the moral reasoning as similar as owned by individual, then the moral reasoning cannot increase (permanent). Concerning with the moral reasoning promoting mechanism, Reimer et al (1979: 147) told that "role taking opportunities stimulate moral development". Role taking was the cognitive competence to see other's perspective (Arbuthnot and Faust, 1981). Arbuthnot and Faust (1981) also told that moral development was stimulated by socio-cognitive conflict result. A moral conflict is a conflict between competing claims of men: you versus me, you versus him" (Boyd, 1976: 57). The contradiction purposed here was in related to structure, not content, in accordance with the moral reasoning theory position as theory including cognitive theory.

There are strong factor that is able to disturb Javanese ethnic's moral reasoning promotion to the postconventional level, namely the existing of a Javanese's obedience on values internalized by parent who also oriented dominantly interdependent and owning conventional moral reasoning. Meanwhile, here are also a number of person in society refereeing to moral reasoning values of conventional level.

\section{Conclusions}

Life view of ngeli nanging ora keli to Javanese ethnic strengthened by mature moral reasoning, overcomes the interdependent cultural bias, in order to be able to function as strong moral control in facing life fluctuation in the 4.0 industrial revolution era. To achieve this, a Javanese needs postconventional moral reasoning stimulation and owns the independent cultural values besides the interdependent ones, with competence to place on the appropriate situation.

\section{Acknowledgments}

Writer thanks to Prof. Dr. Abdul Murad, MPd., who provides valuable contribution. Thanks to Dean of faculty of education science and Rector of Medan State University who provides funding so this paper could be presented on the Education National Convention Indonesia (KONASPI IX) 2019 and International Conference.

\section{References}


Amanda, M. L. (2018). Pengaruh Kontrol Kognitif dan Interaksi Teman sebaya terhadap Pertimbangan Moral Siswa SMA Neg. 12 Medan. Medan: University of Medan Area.

Arbuthnot, J. B. \& D. Faust. (1981). Teaching and Moral Reasoning: Theory and Practice. New York: Harper \& Row.

Badan Pusat Statistik. (2018). Statistik Indonesia. https://www.bps.go.id.

Badan Statistik Nasional. (2010). http://id.m.wikipedia.org/wil

Damanik. I. K. (2018). Pengaruh IQ dan Lingkungan Sekolah terhadap Pertimbangan Moral Siswa SMA Negeri 12 Medan. Tesis. Medan: Universitas Medan Area.

Geertz, H. (1982). Keluarga Java. Jakarta: Grafiti Pers.

Ginsburg, H. \& S. Opper. 1979. Piaget's Theory of Intellectual Development. New Jersey: Prentice-Hall. Inc.

Kitayama, S. \& H. R. Markus. (2004). Kebudayaan dan Diri. Dalam Matsumoto. (1999). Pengantar Psikologi Lintas Budaya. Terjemahan A. Aditomo. Yogyakarta: Pustaka Pelajar Offset.

Kolberg, L. \& D. Candee. 1984. The Relation of Moral Judgment to Moral Action. In Kurtines, W. M. \& J. L. Gewirtz (Ed.). Morality, Moral Behavior, and Moral Development. New York: A Wiley-Interscience Publication John Wiley \& Sons.

Lickona, T. (1976). Critical Issues in the Study on Moral Development and Behavior. In Lickona, Thomas (Ed.). Moral Development and Behavior: Theory, Research, and Social Issues, halaman 3-27. New York: Holt, Rinehart \& Winston.

Maryani, N. (2005). Hubungan antara Partisipasi dalam Organisasi dengan Penalaran Moral pada Remaja Akhir. Skripsi. Bandung: Universitas Padjadjaran Bandung.

Matsumoto, D. (2000). Culture and Psychology: People around The World. Second Edition. Australia: Wadsworth Thomson Learning, Inc.

Menanti, A. (2008). Kontribusi Persepsi remaja Mengenai Teknik Pendisiplinan yang Dilakukan oleh Orang Tua dan Pemahaman Diri Interdependen Remaja terhadap Penalaran Moral Remaja. Disertasi. Bandung: Universitas Padjadjaran.

Menanti, A.(2003). Perbedaan Penalaran Moral SiswaUnggulan dan Nonunggulan di SMU Negeri IV Medan. Skripsi. Medan: Universitas Medan Area.

Monks, F. J., A. M. P. Knoers, S. R. Haditono. 2002. Psikologi Perkembangan. Yogyakarta: Gajah Mada University Press.

Oki, P. S. (2007). Studi mengenai Tahapan Moral Judgment pada Mahasiswa yang Melakukan Perilaku Mencontek Saat Ujian. Skripsi. Bandung: Universitas Padjadjaran.

Republic of Indonesia. Government Rule No 87 Year 2017 on Character Education Reinforcement.

Reimer, J. D. P. Paolitto, R. H. Hers. (1983). Promoting Moral Growth: From Piaget to Kohlberg, Second Edition. New York: Longman, Inc.

Rest, J. R. 1979. Revised Manual for The Defining Issues Test: An Objective Test of Moral Judgment Development. Minneapolis: Minnesota Moral Research Projects.

Rosito, A. C. (2006). Hubungan antara Religiusitas dengan Penalaran Moral pada Remaja Akhir. Skripsi. Bandung: Universitas Padjadjaran.

Setiono, K. (1994). Perkembangan Moralitas dari Sudut Pandang Budaya Jawa. Jurnal Psikologi. 1994, Nomor 2. John S. Nimpoeno (Ed.). Bandung: Fakultas Psikologi Universitas Padjadjaran.

Setiono, K (1982). Perkembangan Kognisi Sosial Mahasiswa. Disertasi. Bandung: University of Padjadjaran.

Sigiro, E. L. (2018). Pengaruh Interaksi Sosial dan peran Gender terhadap Pertimbangan Moral Siswa SMA Negeri 12 Medan. Tesis. Medan: Universitas Medan Area.

Sinaga, J. (2018). Pengaruh Pola Asuh dan Kecerdasan Emosi terhadap Pertimbangan Moral Siswa SMA Negeri 12 Medan. Tesis. Medan: Universitas Medan Area. 
RedWhitepress Global Conferences Series: Social Sciences, Education and Humanities (GCSSSEH), Volume 3, 2019

Steinberg, L. 2002. Adolescence. Sixh Edition. Boston: McGraw-Hill.

Supartini, Y. (1999). Hubungan antara Persepsi tentang Pembinaan Pramuka dengan Penalaran Moral. Skripsi. Bandung: Universitas Padjadjaran.

Suseno, Franz Magnis. (1988). Sebuah Analisis Filosopi tentang Kebijaksanaan Hidup Jawa. Third printed. Jakarta: Gramedia.

Republic of Indonesia. Law No. 20 Year 2003 on National Education System

Velasque, M. G. (2002). Business Ethics: Concepts and Cases. Fifth Edition. New Jersey: Prentice Hall. 